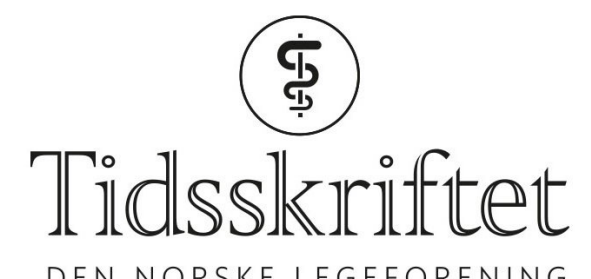

DEN NORSKE LEGEFORENING

\title{
Uten mat og drikke duger helten ikke
}

ANMELDELSER

JAN OLE RØVIK

Ph.d., spesialist i psykiatri og avtalespesialist, Institutt for psykoterapi, Universitetet i Oslo

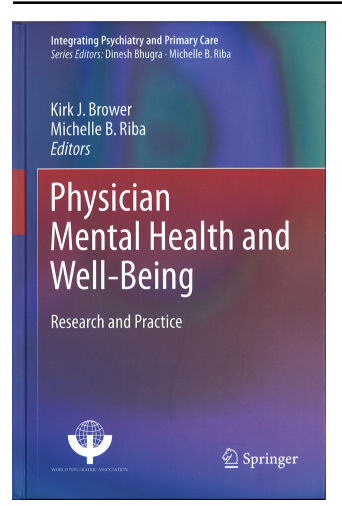

Kirk J. Brower

Michelle B. Riba, red.

Physician mental health and well-being

Research and practice. 326 s, tab. Cham: Springer, 2017. Pris EUR 6o

ISBN 978-3-319-55582-9

Denne amerikanske boken er skrevet for dem som har leger i behandling, og andre som får erfaring med leger med problemer. Det kan dreie seg om mentale helseproblemer, utbrenthet eller vansker med å regulere en stressende jobb og livssituasjon.

Boken har tre hoveddeler. Første del omhandler problemer blant leger slik de presenterer seg, andre del dreier seg om underliggende kliniske problemer og den tredje delen om intervensjoner. Et kapittel om personlighet har norsk forfatter. Innvevd i noen av kapitlene finner vi kliniske vignetter som gir luft og liv til de grundige og oppdaterte forskningsreferansene som boken er spekket med. Vi blir her også informert om hvor det er behov for ytterligere forskning. Longitudinelle studier trengs for å klargjøre komplekse kausalitetsmodeller.

En grunnidé er at god pasientomsorg også betinger omsorg for legene. Vi vet at mange leger nødig søker hjelp. Forhåpentligvis kan denne utgivelsen bidra til lavere terskel for å søke hjelp og veiledning. Utover den enkelte leges situasjon vektlegger forfatterne betydningen av å arbeide med mer systematiske støtteordninger. De illustrerer også et nyere skifte i tenkningen - fra problemløsning til styrking av positive sider ved arbeidet. Intervensjoner 
på organisasjonsnivå blir viktige.

Jeg synes bidragsyterne tar opp viktige problemstillinger for den enkelte lege og

helsevesenet som system. Mange leger opplever det økende meningsløst å bruke mindre tid til direkte pasientarbeid og mer tid til administrativt arbeid man ikke er utdannet til. Det kan disponere for utbrenthet og andre mentale helseproblemer. Jeg synes denne boken burde vært obligatorisk kunnskap for helsebyråkrater og avdelingsledere rundt om i det ganske land.

I min tid som lege i utdanning i psykiatri ved Lovisenberg psykiatriske avdeling sa en veileder til meg at det er et paradoks at pasientarbeid tar lenger tid hvis du skynder deg. Først når du tar deg tid, skapes rom for å ta imot pasienten. På samme måte tror jeg vi kan si at det er først når søkelyset skifter retning fra effektivisering av legens arbeidshverdag til ivaretakelse og omsorg for legene, at legen blir en god og effektiv kliniker. Dette er i tråd med budskap i denne boken.

Publisert:3. september 2018. Tidsskr Nor Legeforen. DOI: 10.4045/tidsskr.18.0293

(C) Tidsskrift for Den norske legeforening 2020. Lastet ned fra tidsskriftet.no 